\title{
Analysis of Cancer Patients Characteristics and the Self-ruqyah Treatment to the Patients Spiritual Life Quality
}

\author{
M. Fais Satrianegara ${ }^{1 *}$, Anwar Mallongi ${ }^{2}$ \\ ${ }^{1}$ Faculty of Medicine and Health Sciences, Alauddin State Islamic University, Makassar, Indonesia; ${ }^{2}$ Department of Environmental \\ Health, Faculty of Public Health, Hasanuddin University, Makassar, Indonesia
}

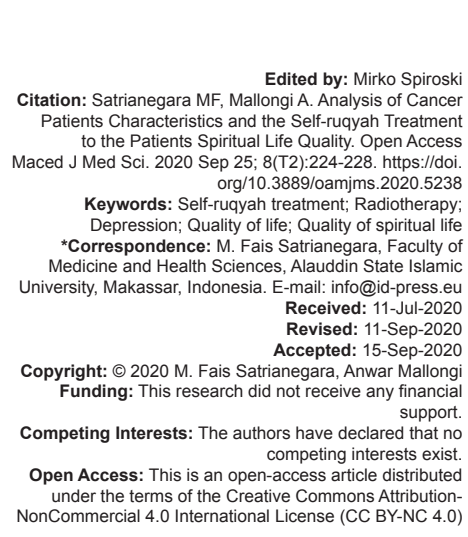

\section{Introduction}

Within a period of 10 years, it was seen that the ranking of cancer as a cause of death rose from rank 12 to rank 6. Every year there are estimated to be 190 thousand new sufferers and one-fifth will die from this disease [1]. Indonesia was a developing country with a fairly high prevalence of cancer. In the ASEAN region, Indonesia ranks second after Vietnam with cancer cases reaching 135,000 cases per year. The data are almost the same as that found by the Center for Data and Information Pusdatin) Ministry of Health of the Republic of Indonesia (2007) which mentions the prevalence of cancer reaching 100 thousand per year. In Indonesia, cancer is the second leading cause of death after heart disease [2], [3].

Quality of life according to the World Health Organization Quality of Life (WHOQOL) Group is defined as an individual's perception of the position of individuals in life in the cultural context and value system in which individuals live and their relationship to goals, expectations, standards set, and one's attention. One of the instruments for QL is WHOQOL-BREF.
This instrument includes four dimensions: (1) Physical health, including daily activities; dependence on drugs; energy and fatigue; mobility; pain and discomfort; sleep and rest; and work capacity; (2) psychological welfare, including bodily image and appearance; negative feelings; positive feelings; self-esteem; spiritual/ religious/personal beliefs, thinking, learning, memory, and concentration; (3) social relations, including personal relationships, social support; and sexual activity; (4) relationship with the environment, including financial resources; freedom, security, and physical safety; health and social care including accessibility and quality; home environment, the opportunity to get a variety of new information and skills; participation and the opportunity to engage in recreational and leisure activities; physical environment including pollution/ noise/traffic/climate; and transportation.

M. Faisal Idrus [4] conducted research on HIV/ AIDS sufferers, amounting to 20 patients as a treatment group and 20 patients as a control group. This study uses a quasi-experimental pretest-posttest control group design. From the results of the study, respondents who participated in spiritual psychotherapy through prayer and Dhikr (explanation) by AIDS patients experienced 
a significant increase in serum CD4 + levels and decreased depression [4].

Radiotherapy is a treatment aimed at the possibility of survival of cancer patients after adequate treatment. However, the side effects of radiotherapy allow the emergence of negative physical and psychological impacts on cancer sufferers. Changes in the body's systems and functions that occur in cancer patients can cause disruption of the patient's self-concept that will result in a decrease in the functioning of the body so that sufferers depend on others to meet their basic needs. Changes in self-image due to self-concept disorders occur in all cancer patients and if these changes are not integrated with self-concept, it will result in a decrease in the quality of life [5].

Based on the description, the researchers felt the need to conduct research that sought solutions so that cancer patients who underwent radiotherapy and were at risk of experiencing depression and loss of meaningful spiritual life through a religious psychotherapy approach using the self-ruqyah method (self-healing) as part of alternative interventions in the concept of palliative care in cancer sufferers.

\section{Materials and Methods}

This type of research used in this study, researcher used the observational analytic with 20 respondents who were selected using the purposive sampling technique. The research measured the depression score using the beck depression inventory and the life quality (FACT-G) and the spiritual life quality FACIT Sp.12 (The Functional Assessment of the Chronic Illness Therapy Spiritual) on the case group (experimental) namely 10 cancer patients undergoing the radiotherapy who participated in the self-ruqyah treatment program and the control group namely 10 patients who did not participate in the program.

\section{Place and time of research}

This research was conducted from February to March 2016 in the Radiotherapy Unit of Hasanuddin University Hospital, Makassar, South Sulawesi Province.

\section{Research population}

The population in the study was all cancer patients who underwent complete radiotherapy at the hospital Hasanuddin University, February to March in 2016.

\section{Research samples}

The sample in this study was cancer patients who underwent radiotherapy for 25 days in the hospital, Hasanuddin University meets the inclusion criteria. The sampling technique in this study uses purposive sampling, which is to determine samples that fit the inclusion criteria of 20 respondents selected as samples. In the beginning, the researchers found 26 samples that were willing to be sampled, but in the implementation, there were six samples that dropped out because three people did not continue therapy, two people did not give news, and one person died.

\section{Sample size}

Initially, the study was established using the randomized control group pretest-posttest design model. However, due to the number of cancer patients registered in the radiotherapy installation medical records section who met the inclusion criteria who were willing to be respondents in the two treatment and control groups, only 26 people were divided into 13 treatment groups and 13 control groups. There were two respondents who were initially in the treatment group but because in the observations, they were unable to carry out independent ruqyah on the grounds that they were inconsistent in the therapy visit and inconsistent in carrying out ruqyah, so the researchers included them in the control group. Then, in the observation of 25 days out of 15 people in the control group who were able to survive only 10 people, three others dropped out because they returned to their area two people who had no communication; one person in the treatment group died on the $10^{\text {th }}$ day of observation. Hence, with a total population of 20 people, methodologically, randomization does not meet the conditions. Therefore, 20 patients who met the inclusion criteria were determined as the study sample, so this study was called total sampling.

\section{Drop out criteria}

Research subjects who could not participate in the Ruqyah Mandiri program in the treatment group for 25 days on the grounds that there was no communication so that they were not present at the time of data collection and saliva or died.

\section{Results}

The results of this study illustrate the number of cancer sufferers more female sex that is equal to $65 \%$ while male respondents as much as $35 \%$ (Table 1). 
Table 1: Distribution of cancer patients by gender of cancer patients undergoing radiotherapy at the hospital Hasanuddin University Makassar period February-March 2016

\begin{tabular}{lllllll}
\hline Sex & Group & & & & Total & $\%$ \\
\cline { 2 - 5 } & Intervention & $\%$ & Control & $\%$ & & \\
\hline Male & 5 & 50 & 2 & 20 & 7 & 35 \\
Female & 5 & 50 & 8 & 80 & 13 & 65 \\
Total & 10 & 100 & 10 & 100 & 20 & 100 \\
\hline
\end{tabular}

The risk of the age group, then the age range most often found in this study is the age range of 40-49 years which is as much as $55 \%$, then the age of $50-59$ $(25 \%)$ and the rest in the young age group $(20 \%)$. This is in accordance with cancer studies that have been done showing this age range is the latent period of the pre-invasive phase to become invasive which takes $7-10$ years, so most of it is known after age in this range (Table 2).

Table 2: Distribution of cancer patients by age group of cancer patients who underwent radiotherapy at the hospital Hasanuddin University Makassar period February-March 2016

\begin{tabular}{lllllll}
\hline Age & Group & & & & Total & $\%$ \\
\cline { 2 - 5 } & Intervention & $\%$ & Control & $\%$ & & \\
\hline $30-39$ & 2 & 20 & 2 & 20 & 4 & 20 \\
$40-49$ & 6 & 60 & 5 & 50 & 11 & 55 \\
$50-59$ & 2 & 20 & 3 & 30 & 5 & 25 \\
Total & 10 & 100 & 10 & 100 & 20 & 100 \\
\hline
\end{tabular}

The number of respondents sampled in this study was mostly found in the middle/junior high school education gap of $40 \%$, not at school or elementary school at $35 \%$ and respondents who had a Strata education of $25 \%$ (Table 3 ).

Table 3: Distribution of cancer patients based on cancer patients education who underwent radiotherapy at the hospital Hasanuddin University Makassar period February-March 2016

\begin{tabular}{|c|c|c|c|c|c|c|}
\hline \multirow[t]{2}{*}{ Education level } & \multicolumn{4}{|l|}{ Group } & \multirow[t]{2}{*}{ Total } & \multirow[t]{2}{*}{$\%$} \\
\hline & Intervention & $\%$ & Control & $\%$ & & \\
\hline Basic school & 4 & 40 & 3 & 30 & 7 & 35 \\
\hline Junior and senior high school & 4 & 40 & 4 & 40 & 8 & 40 \\
\hline Higher education & 2 & 20 & 3 & 30 & 5 & 25 \\
\hline Total & 10 & 100 & 10 & 100 & 20 & 100 \\
\hline
\end{tabular}

Almost all patients who were sampled in this study had a permanent job of $30 \%$ as civil servants or $25 \%$ private, the rest stopped working because of suffering from this disease as much as $30 \%$ (Table 4 ).

Table 4: Distribution of cancer patients by type of cancer patients work undergoing radiotherapy at the hospital Hasanuddin University Makassar Period February-March 2016

\begin{tabular}{lllllll}
\hline Occupation & Group & & & & Total & $\%$ \\
\cline { 2 - 5 } & Intervention & $\%$ & Control & $\%$ & & \\
\hline Civil servant & 3 & 30 & 3 & 30 & 6 & 30 \\
Businessman & 3 & 30 & 2 & 20 & 5 & 25 \\
Farmer/worker & 1 & 10 & 2 & 20 & 3 & 15 \\
Not work & 3 & 30 & 3 & 30 & 6 & 30 \\
Total & 10 & 100 & 10 & 100 & 20 & 100 \\
\hline
\end{tabular}

Most of the respondents in the study were married and $85 \%$ and $10 \%$ were divorced and one person or $5 \%$ of respondents were not married (Table 5 ).

Table 5: Distribution of cancer patients based on the marital status of cancer patients undergoing radiotherapy at the hospital Hasanuddin University Makassar period February-March 2016

\begin{tabular}{lllllll}
\hline Marital status & Group & & & Total & $\%$ \\
\cline { 2 - 4 } & Intervention & $\%$ & Control & $\%$ & & \\
\hline Marriage & 10 & 100 & 7 & 70 & 17 & 85 \\
Divorce & 0 & 0 & 2 & 20 & 2 & 10 \\
Not marriage & 0 & 0 & 1 & 10 & 1 & 5 \\
Total & 10 & 100 & 10 & 100 & 20 & 100 \\
\hline
\end{tabular}

Table 6 illustrates that cancer is more dominated by female organ cancer, namely cervical cancer $(35 \%)$, breast $(25 \%)$, and men more suffering from nasopharynx cancer (25\%) and the remaining SCC cancer (15\%) and $5 \%$ who suffer from the disease lung.

Table 6: Distribution of cancer patients by type of diagnosis of cancer patients undergoing radiotherapy at the hospital Hasanuddin University Makassar period February-March 2016

\begin{tabular}{lllllll}
\hline Cancer diagnosis & Group & & & Total & $\%$ \\
\cline { 2 - 5 } & Intervention & $\%$ & Control & $\%$ & & \\
\hline KNF & 3 & 30 & 2 & 20 & 5 & 25 \\
Cervix & 4 & 40 & 3 & 30 & 7 & 35 \\
Mammae & 1 & 10 & 3 & 30 & 4 & 20 \\
SCC & 2 & 20 & 1 & 10 & 3 & 15 \\
Lung & 0 & 0 & 1 & 10 & 1 & 5 \\
Total & 10 & 100 & 10 & 100 & 20 & 100 \\
\hline
\end{tabular}

On average new cancer patients are detected and treated at the hospital when entering Stage III (60\%) and Stage II as much as $35 \%$ while the remaining one is at Stage IV $(5 \%)$. The period of diagnosis of cancer patients is more in the span of $1-2$ years $(55 \%)$ and the period of more than 3 years is $30 \%$. This proves that the changes in the body's systems and functions that occur in cancer patients that cause pain symptoms are very fast development and disrupt the quality of life of cancer sufferers (Table 7).

Table 7: Distribution of cancer patients based on the stage of cancer patients undergoing radiotherapy at the hospital Hasanuddin University Makassar period February-March 2016

\begin{tabular}{lllllll}
\hline Cancer stadium & Group & & & Total & $\%$ \\
\cline { 2 - 5 } & Intervention & $\%$ & Control & $\%$ & & \\
\hline II & 2 & 20 & 5 & 50 & 7 & 35 \\
III & 7 & 70 & 5 & 50 & 12 & 60 \\
IV & 1 & 10 & 0 & 0 & 1 & 5 \\
Total & 10 & 100 & 10 & 100 & 20 & 100 \\
\hline
\end{tabular}

Table 8 illustrates the length of diagnosed patients generally ranges from less than a year $(40 \%)$ and the length of diagnosed patients ranges from 1 to 2 years by $30 \%$ and respondents who have been diagnosed for longer than 3 years by $30 \%$.

Table 8: Distribution of cancer patients based on the length of diagnosed with cancer patients who underwent radiotherapy at the hospital Hasanuddin University Makassar period February-March 2016

\begin{tabular}{lllllll}
\hline Diagnoses duration & Group & & & Total & $\%$ \\
\cline { 2 - 5 } & Intervention & $\%$ & Control & $\%$ & & \\
\hline$<1$ year & 2 & 20 & 6 & 60 & 8 & 40 \\
1-2 year & 3 & 30 & 3 & 30 & 6 & 30 \\
$>3$ year & 5 & 50 & 1 & 10 & 6 & 30 \\
Total & 10 & 100 & 10 & 100 & 20 & 100 \\
\hline
\end{tabular}

\section{Discussion}

\section{Effect of self-ruqyah to the improvement of cortisol level of cancer patient}

Long-term stress and depression will result in a continuous flow of the hormones adrenaline and cortisol into the blood and cause damage to the body's systems. High adrenaline levels that last for a long time can increase heart rate and blood pressure to a point where the body is accustomed to this state and assume this is a normal condition. High levels of adrenaline 
can cause blood to clot more easily and cause clogged arteries, thyroid to be overactive, and the body to produce more cholesterol. This, of course, can result in body crunching which results in terminal diseases such as cancer, diabetes, and stroke [6].

HerbertBenson in his bookentitled Healing Faith states that certain meditation and prayer movements can be used to evoke a relaxation response. Where the movement is actually a simple technique consisting of a four-step procedure that includes; (1) find a quiet environment, (2) consciously relax the muscles of the body, (3) concentrate for ten to twenty minutes on mental devices, such as one words or short prayers, and (4) be passive about the mind-disturbing thoughts by Herbert Benson and William Proctor [7]. Research has found how many psychological treatments explain the decline in body stimulation conditions caused by stress. The most well-known psychological method is progressive meditation and relaxation. The relaxation response method found by Herbert Benson can actually be found when people pray or Dhikr. For meditators or people who frequently do activities such as Dhikr also produce more alpha waves, namely brain waves associated with relaxation or calm/relax points [8]. The combination of relaxation response techniques with individual belief systems such as the independent ruqyah movement is actually a movement that represents the whole simple technique that Herbert Benson calls Faith Factor.

\section{Effect of ruqyah Mandiri on decreasing depression of cancer patients}

Humans have a balance regulating mechanism in the body's metabolic system known as homeostasis, for example the skin's pores shrink from cold to avoid loss of body heat. When we react positively to mild stress, PMOC (proopiomelanocortin) is formed by the adrenal cortex hormone that relieves physical stress. In addition, betaendocrine which counteracts psychological stress will also be released. Interestingly, beta-endorphins are antidotes to stress if we react with positive thoughts. Conversely, the two hormones will not be released if we react negatively and reject. The conclusion is that the body will produce substances that function as drugs if every stimulus is responded with positive thoughts [8]. With positive thinking, the objects that are around us will depend on how we perceive and perceive them. Conversely, if a person often does negative mental activities, such as negative thinking, he will be encouraged to always think negatively [9].

The results of this study are in line with research conducted by Faisal Idrus, who examined the role of spiritual psychotherapy in providing peace, peace, and happiness of the souls of people with HIV/ AIDS. Faisal's research concludes that mental calm is expected to reduce depression which will evoke an individual body's immune response [10]. Another study that supports the results of this study is a study conducted by Subandi that assesses Dhikr also has a high therapeutic value. Stress and depression have effects on psychological health and health care needs because depressed patients increase their stay in the hospital and increase the cost of medical services, in addition to affecting the quality of life of patients and their families [11].

The influence of negative thoughts and emotions will trap someone in the maladaptive coping mechanism by Antoni [12] so that it will hamper the function of integration, breakdown growth, and reduce autonomy and tend to control the environment, such as withdrawal attitude, do not want to tell the problem of pain, finish yourself in bed, and prejudiced against the destiny of his Lord. Biologically, stress can cause the liver to produce more free radicals in the body. Besides, stress can affect and decrease the body's immune function (immunity), so it is vulnerable to infectious diseases and cancer. If stress cannot be overcome, it will continue to become depressed [13].

\section{Effect of self-ruqyah in improving the quality of life of cancer patients}

Recent research results conclude that neuropsychological complications (such as emotional, behavioral, and cognitive disorders) can not only have a negative impact on the social functioning of stroke patients and their overall quality of life but also have an influence on healing their motor functions. The implication, the development of skills and religious behavior or religious coping is highly recommended as strength for individuals to face the demands of increasing work stress [15]. Psychophysiological effects of distress have a negative impact on the physical and psychological health of individuals. The sympathetic nervous system works through the stimulation of the hypothalamus and spinal cord due to stress stimulation. The operation of the sympathetic nervous system has an impact, among others, namely increasing blood pressure, increasing total energy consumption, increasing blood pressure, increasing total energy consumption, increasing blood glucose concentration, increasing energy release in muscles, increasing muscle tension, increasing mental activity, and increase the level of blood coagulation [16].

\section{The influence of self-ruqyah on improving quality of life}

\section{Spiritual cancer patients}

Based on the results of statistical tests on the variable quality of spiritual life, it is known that there are differences in the mean, so it can be concluded that there is a relationship between the independent ruqyah program to increase the spiritual quality of life of cancer patients undergoing radiotherapy. The difference in the score of quality of spiritual life during therapy before and after the intervention of religious psychotherapy illustrates 
that the spiritual quality of life of cancer patients has increased significantly. The results of in-depth interviews with respondents who have done an independent ruqyah feel an increase in the quality of spiritual life that has a positive impact on their positive emotions on the environment of their friends and family. There are three subscales measured from the FACIT spiritual quality of life scale. The three scales are (1) meaningfulness of life which is a description of the reason he lives, the meaning and purpose of life felt by the sufferer, (2) peace, comfort, and perceived harmony sufferers, and (3) efforts to strengthen their faith and strength in perceived faith, and belief in healing (Peterman et al., 2002).

\section{Conclusion}

1. There are differences in the mean cortisol levels in cancer patients who do independent ruqyah therapy and who do not do independent ruqyah

2. There are differences in the mean value of depression in cancer patients who do independent ruqyah therapy and who do not do ruqyah independently

3. There are differences in the average value of quality of life in cancer patients who do independent ruqyah therapy and who do not do ruqyah independently

\section{References}

1. Diananda R. Mengenal Seluk-Beluk Kanker (Cetakan 3). Yogyakarta: Katahati; 2009.

2. Departemen Agama Republik Indonesia. Al-Qur'an dan Terjemahannya. Surabaya: Pustaka Agung Harapan; 2006.
3. Departemen Kesehatan Republik Indonesia. Sistem Kesehatan Nasional. Jakarta: Departemen Kesehatan Republik Indonesia; 2009. https://doi.org/10.6066/ jtip.2013.24.2.121

4. Idrus MF. Spiritual Psychotherapy Effect to Increase Cd4+ Count in HIVIAIDS Patients. Alamat Korespondensi . Makassar: Faisal Idrus Universitas Hasanuddin; 2012.

5. Indrayani D. Pengalaman Hidup Klien Kanker Serviks di Bandung. Bandung: Universitas Padjajaran; 2007.

6. Gunawan AW. The Miracle of Mindbody Medicine, How to Use your Mind for Better Health. Jakarta: PT Gramedia Pustaka Utama; 2012.

7. Benson H, Proctor W. In: Nilandari A, editor. Keimanan Yang Menyembuhkan Dasar-Dasar Respon Relaksasi. Bandung: Kaifa; 2000.

8. Sukmono RJ. Psikologi Dzikir. Jakarta: Sri Gunting; 2008.

9. Haruyama DS. Sehat Mudah dan Praktis Dengan Hormon Kebahagiaan. Bandung: Qanita; 2011.

10. Bajry HA. Tubuh Anda Adalah Dokter Yang Terbaik. Bandung: MQS Publishing; 2010.

11. Hidayati WC, Rochmawati DH. Pengaruh terapi religius zikir terhadap peningkatan kemampuan mengontrol halusinasi pendengaran pada pasien halusinasi Di RSJD Dr. Amino Gondohutomo Semarang. J IImu Keperawatan Kebidanan. 2014:1-9.https://doi.org/10.33757/jik.v1i1.24

12. Goldney R, Fisher L, Dal Grande E, Taylor A. Subsyndroma depression: Prevalence, use of health services and quality of life in an Australian Population. Soc Psychiatry Psychiatr Epidemiol. 2004;39:293-8. https://doi.org/10.1007/ s00127-004-0745-5

13. Antoni $\mathrm{MH}$. Psychosocial intervention effects on adaptation, disease course and biobehavioral processes in cancer. Brain Behav Immun. 2013;30:S88-98. https://doi.org/10.1016/j. bbi.2012.05.009 PMid:22627072

14. Wardhana WA. Strategi Mengatasi dan Bangkit Dari Stroke. Yogyakarta: Pustaka Pelajar; 2011.

15. Noor NM. Work and women's well-being: Religion and age as moderators. J Relig Health. 2008;47:476-90. https://doi. org/10.1007/s10943-008-9188-8

PMid: 19093675

16. Safaria T, Saputra NE. Manajemen Emosi. $1^{\text {st }}$ ed. Jakarta: Bumi Aksara; 2009. 